\title{
Geospatial analysis of fortification locations on the island of Tongatapu, Tonga
}

\author{
Christian Reepmeyer, Geoffrey Clark, Phillip Parton, \\ Malia Melekiola and David Burley
}

\section{Introduction}

Recent research investigating earthwork fortifications on Tongatapu, Kingdom of Tonga, using lidar data identified numerous defensive sites on the island (Parton et al.2018), with the antiquity of the earliest building phase dating to at least 1300 CE (Clark et al. 2018; Spennemann 1989). This corresponds well with the hypothesis that fortifications appear in the Pacific at 13001800 CE (Field 2008). However, it is widely held that most fortifications on Tongatapu were constructed during the civil war era, from 1799 to 1852 CE (McKern 1929; Spennemann 1986; Wood 1975). Beyond questions about the exact timing of initial fortification construction, there is considerable debate about the reasons populations need to defend their land. This debate is not limited to Tonga, as it has been suggested that environmental factors and climate shifts played a significant role in the emergence of social conflict in the Pacific in general (Field 2004; Field and Lape 2010).

The selection of natural defensive locations on islands has been reported from numerous parts of Oceania (Field 2008). Hill fort/ridgeline location is a common occurrence on well-researched island groups, such as Fiji (Best 1993) and Samoa (Golson 1969). This argument is also reflected in previous descriptions of fort construction under Tongan influence, such as Spennemann's (1989:481, see also Best 1993) assertion that Tongans constructed a large upland fort on the island of Lakeba in east Fiji:

\section{Tongans were actually responsible for the erection of the Ulunikoro fortification, and Best's argument appears convincing in the light of present evidence, it is a good example to show that fortification types are predominantly governed by topographical conditions rather than by 'cultural' traits.}

In this chapter, we report geospatial analyses of earthwork fortifications on Tongatapu (Figure 9.1). Our primary concern is the location of forts in the landscape rather than the age of defensive sites as the majority of Tongatapu forts are currently undated. In addition, we focus on enclosed/partially enclosed earthwork fortifications that are the dominant type of defensive site on Tongatapu compared with the small number of linear earthworks (Parton et al. 2018). Tongatapu is a low-lying limestone island with few natural defences. There are no steep escarpments on the lagoon side of the island, and few inland high points or vertical ridges. 


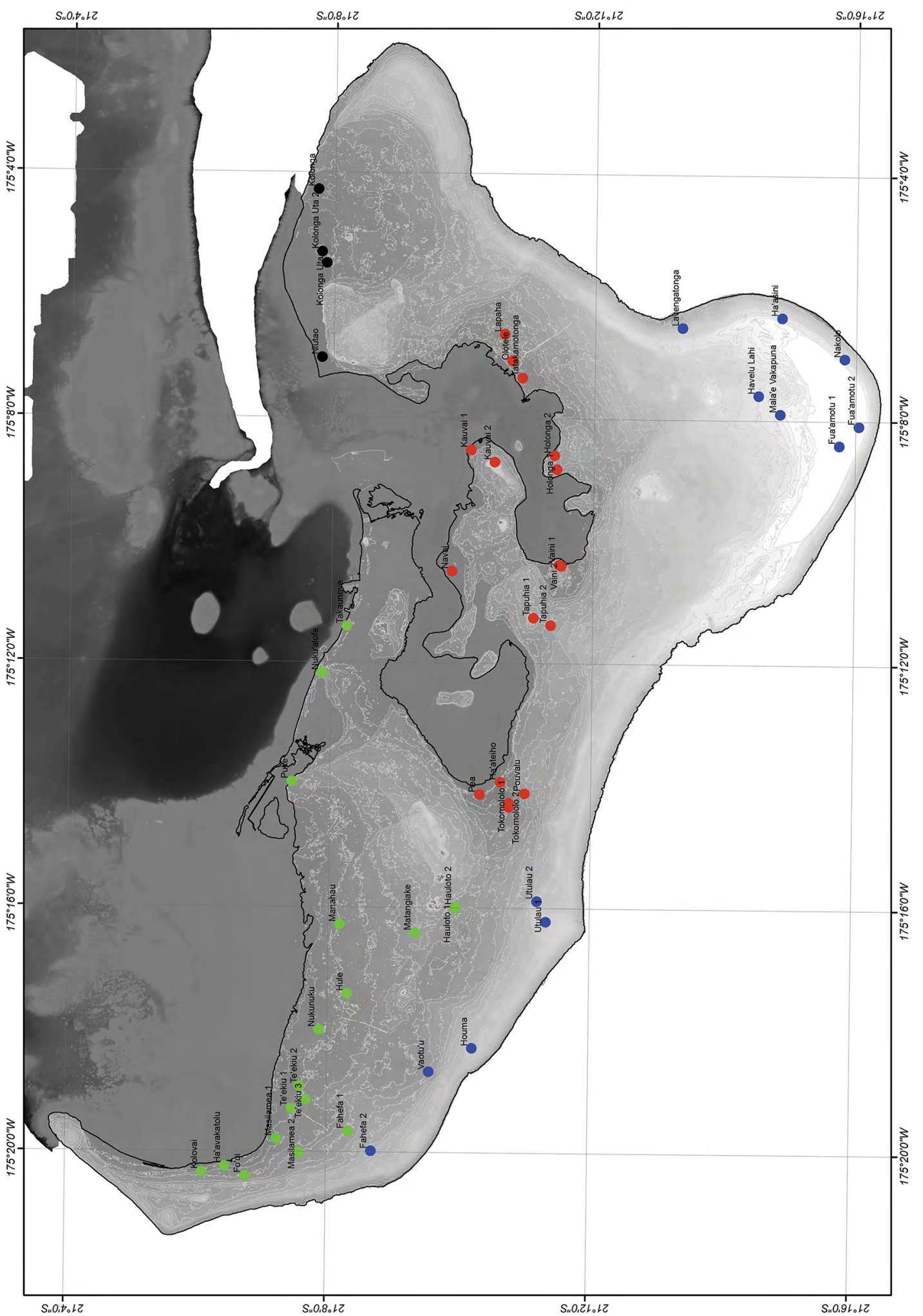

Figure 9.1. Topographic map ( $2 \mathrm{~m}$ isoclines) of Tongatapu with lidar digital elevation model (DEM) and site location of fortifications.

Locations in blue are on limestone ridges, green are low-lying coastal areas, red associated with the Fanga 'Uta Lagoon and black are sites on the north-east coast.

Source: Christian Reepmeyer, Geoffrey Clark, Phillip Parton, Malia Melekiola and David Burley. 
Using the lidar dataset of enclosed forts identified (Parton et al. 2018), we examine the association of forts with natural features. The currently dominant hypothesis about the location of forts in the Pacific is that they are placed on high points/defendable areas in close proximity to a group's agricultural land (Field 2008). This is the proposed explanation for the focus of many Maori $p a$ (earthwork defences) in New Zealand on high points along the coast and river systems of the North Island (e.g. Anderson 2016). Similarly, in the Sigatoka Valley, Fijian forts were established overlooking gardens (wetland vuci or dryland were) or were defended settlements located within field systems (Best 1984; Parry 1987). As Field (1998:33) notes, the association between defences and tuber cultivation aligns with the tenets of evolutionary ecology, which have increasing competition for resources as a catalyst for group formation, territorial defence and the intensification of cultivation.

There are also forts in west and east Fiji positioned in often inaccessible and high areas away from main gardens that likely functioned as territorial refuges. These forts are built and traditionally occupied by non-locals, particularly Tongans, in Fiji, Samoa and 'Uvea (Best 1993; Sand 2008). There is a high likelihood that some defensive sites were made to control strategic locations and non-agricultural resources (Best 1984; Clark et al. 2018). The topographic features of Tongatapu forts examined here were elevation, elevation difference to surrounding landscapes (peaks), slope, distance to coast, distance to potential freshwater sources and soil quality. Visibility has been considered important for site location on Fiji (Field 1998; Smith and Cochrane 2011) and we conducted an initial intervisibility analysis to examine geospatial relationships between sites.

\section{Geographical aspects of fortification location}

The analysis is based on high-resolution contours interpolated from a lidar digital elevation model (DEM; for a detailed description of the methods used, see Parton et al. 2018) combined with information from the Tonga Government Ministry of Land, Survey and Natural Resources geospatial database. The low relief and generally gentle topography of Tongatapu, in addition to the intensive agricultural usage of most of the land, allowed standard lidar visualisation techniques to view and interpret archaeological features. In some areas, however, urban development had severely degraded or even destroyed portions of earthworks. All lidar visualisations used the contractor-supplied $1 \mathrm{~m} \mathrm{DEM}$ as a base from which additional visualisations were prepared. Examination of the DEM was conducted using 'default' hillshade algorithms that are standard in ArcGIS packages (ESRI 2011). The basic visualisation revealed a number of archaeological features present in the lidar data, including mounds, chiefly tombs, sunken roads and defensive structures.

\section{Physical geography of Tongatapu}

Tongatapu is a low-lying raised limestone island overlain by andesitic tephras of variable depth (Cowie 1980; Gibbs 1976). Its current geomorphology originates from six phases of volcanic activity, which uplifted the island to $65 \mathrm{~m}$ above sea level in the south-east (Taylor 1978). From this high point the island slopes gently to the north and north-west, and to the coast. Most of the island has a flat relief, with slopes less than five degrees. There are a few areas with rolling slopes, particularly on the southern side of the island. These have developed on undulating reef platforms and reflect relict reef outcrops within the original lagoon and barrier reefs along the coastal margins. Low scarps can be seen across the island, but are commonly covered by thinner overlain tephras, which are deeper in the depressions in between. There is a general trend in soil thickness from west to east, with soils reaching $2 \mathrm{~m}$ deep in the western end decreasing to around $0.4 \mathrm{~m}$ in the eastern end of the island (Cowie 1980). 
On the south side of the island, the rocky liku coastlines are mostly steep, rising to $35 \mathrm{~m}$ above sea level. These steep coasts are interrupted by small pocket beaches, most likely originating from erosion of sinkholes and coastal limestone. No reef passages exist on the south side of the island (Taylor 1978) but there are rare deep water channels to the north. The south coast of the island is highly dynamic, whereas the northern leeward side of the island receives little wave action and is sheltered from tidal action by a lagoon fronted by a series of outer islands. The Fanga 'Uta Lagoon is the main feature of central-north Tongatapu and has large areas of mangrove. The lagoon is shallow and the western part is now enclosed by land and is connected to the sea by tidal channels.

\section{Spatial patterning of fort distribution}

Forts on Tongatapu occur in four different geospatial locations: (1) uplifted limestone ridges on the south coast; (2) low-lying coastal areas in the north, and particularly in the western part of the island; (3) coastal areas around the Fanga 'Uta lagoon; (4) along, or close to, the uplifted, low-elevation limestone coast in the north-east.

1. Uplifted limestone ridges. These are areas close to the rocky liku coast, at an elevation of $>16 \mathrm{~m}$ above sea level. Seven forts are located on raised limestone platforms, particularly in the south and south-eastern part of the island along the coast to the east. These forts are: 38-Havelu Lahi, 39-Mala'e Vakapuna, 40-Fua'amatu and 41-Fua'amatu, 42-Nakolo, 43-Ha'́asini and 44Lavengatonga (Figure 9.1). Similar locations in the west of the island are occupied by the forts of: 9-Fahefa, 10-Fahefa, 13-Vaotu'u, 14-Houma and 19-'Utulau and 20-'Utulau.

2. Low-lying coastal. The second group of fortifications are located on low-lying areas mainly in the west. These include: 1-Kolovai, 2-Ha'avakatolu, 3-Fo ui, 4-Masilamea and 5-Masilamea, 6-Te'ekiu, 7-Te'ekiu and 8-Te'ekiu, 11-Nukunuku, 12-Hule and 15-Manahau. Two forts (27Nuku'alofa and 28-Takaunove) are directly associated with coastal areas that are now incorporated within the capital of Nuku'alofa with 21-Puke further west. Three forts not associated with the coastline, but still located on low-lying near-coast areas are: 16-Matangiake, 17-Hauloto and 18-Hauloto.

3. Fanga 'Uta Lagoon. Forts directly associated with the Fanga 'Uta Lagoon in the centre of the island are located in two distinct groups. The western group consists of 22-Pea, 23-Ha'ateiho, 24-Tokomololo and 25-Tokomololo and 26-Pouvalu; the eastern group comprises 36-Holonga and 37-Holonga, 45-Tatakamotonga, 46-Olotele and 47-Lapaha, and on the opposite site of the lagoon, 29-Navai, 30-Tapuhia, 31-Tapuhia, 32-Kauvai and 33-Kauvai and 34-Vainī and 35-Vainī.

4. North-east coast. Finally, 48-Niutao, 49-Kolonga'Uta 1 and 50-Kolonga'Uta 2, and 51Kolonga are situated on the north-east coast. Two of these forts are low-lying, with 48-Niutao in a coastal swamp and parts of the ditches made at 49-Kolonga'Uta 1 and 50-Kolonga'Uta 2 carrying water after heavy rainfall and high tide events.

\section{Elevation}

Fortifications on Tongatapu can be found on all elevations; however, they tend to be more common at lower elevations (Table 9.1). Twenty-six forts are located at an elevation of $<6 \mathrm{~m}$, 13 forts are at an elevation of $7-15 \mathrm{~m}$ and only 12 forts are at an elevation of $18 \mathrm{~m}$ or higher, with the highest elevation recorded at $62 \mathrm{~m}$ (41-Fua'amotu). This reflects the overall landforms of Tongatapu, which gently rise from the low-lying areas in the north and north-west to the higher elevations of the south and east. 
In general, there is little evidence that forts were concentrated along certain elevations; rather, they were built on all landforms. The prevalence of forts at lower elevations indicates that elevation by itself was not a determining factor. In some areas, raised elevations have been actively avoided, such as at the forts of 49-Kolonga' $U$ ta and 48-Niutao on the east side of the island, 1-Kolovai in the west and 17-Hauloto and 18-Hauloto in the centre of the island. The topography of Tongatapu only rarely has slopes with a gradient of more than 5 per cent. There are a few locations in the west, such as 19-'Utulau and 20-'Utulau, 14-Houma or 10-Fahefa that are on elevated areas on the uplifted southern border of the island. These, however, are not located backing toward the shoreline but several hundred metres away from any steep slope or cliff edge. Even at the highest elevation, such as the cluster of sites in the south-east corner of the island, namely 40-Fua'amotu and 41-Fua'amotu, 42-Nakolo and 43-Ha'asini, forts are not located in close vicinity to what might be assumed to be the 'best' naturally defended location. The forts 42-Nakolo, 43-Ha'asini and 44-Lavengatonga are not placed on top of the ridgeline itself, but rather on the down-sloping area that leads to the south coast, where there are steep cliffs that would provide difficult access if the cliff top was defended.

Table 9.1. Site names/locations for fortified sites on Tongatapu with basic geographic data for elevation, slope, distance to coast, distance to water sources and soil types.

\begin{tabular}{|c|c|c|c|c|c|c|c|}
\hline & Name & $\begin{array}{l}\text { Elevation } \\
\text { (m) }\end{array}$ & $\begin{array}{l}\text { Peaks and } \\
\text { ridges }\end{array}$ & $\begin{array}{c}\text { Slope } \\
(\%)\end{array}$ & $\begin{array}{c}\text { Distance to } \\
\text { coast (m) }\end{array}$ & $\begin{array}{l}\text { Distance to } \\
\text { fresh water }(\mathbf{m})\end{array}$ & Soil type \\
\hline 1 & Kolovai & 2.7 & No & 2.52 & 220 & 447 & Fatai \\
\hline 2 & Ha‘avakatolu & 2.4 & No & 0.92 & 119 & 312 & Sandy loam \\
\hline 3 & Fo'ui & 6.3 & No & 0.28 & 524 & 325 & Fatai \\
\hline 4 & Masilamea & 4.7 & No & 0.8 & 271 & 197 & Fatai \\
\hline 5 & Masilamea & 8.3 & No & 1.54 & 1020 & 343 & Fatai \\
\hline 6 & Te‘ekiu & 3.8 & No & 0.46 & 561 & 673 & Fatai \\
\hline 7 & Te‘ekiu & 2.8 & No & 0.36 & 744 & 419 & Fatai \\
\hline 8 & Te‘ekiu & 4.8 & No & 0.93 & 965 & 462 & Fatai \\
\hline 9 & Fahefa & 10.2 & No & 0.24 & 1664 & 334 & Fatai \\
\hline 10 & Fahefa & 18.5 & No & 8.75 & 1008 & 450 & Fatai \\
\hline 11 & Nukunuku & 3.8 & No & 1.23 & 770 & 83 & Fatai \\
\hline 12 & Hule & 4.4 & No & 0.71 & 1214 & 146 & Fatai \\
\hline 13 & Vaotưu & 11.0 & No & 1.05 & 965 & 202 & Fatai \\
\hline 14 & Houma & 23.2 & Possible & 1.92 & 560 & 812 & Fatai \\
\hline 15 & Manahau & 4.6 & No & 0.22 & 754 & 210 & Fatai \\
\hline 16 & Matangiake & 9.6 & No & 0.42 & 2895 & 515 & Fatai \\
\hline 17 & Hauloto & 9.6 & No & 0.23 & 3234 & 72 & Fatai \\
\hline 18 & Hauloto & 9.8 & No & 0.6 & 3235 & 83 & Fatai \\
\hline 19 & ‘Utulau & 26.0 & Possible & 0.46 & 1002 & 447 & Fatai \\
\hline 20 & ‘Utulau & 22.3 & Possible & 0.43 & 1298 & 264 & Fatai \\
\hline 21 & Puke & 4.4 & No & 0.81 & 67 & 250 & Fatai \\
\hline 22 & Pea & 2.4 & No & 4.03 & 276 & 374 & Fatai \\
\hline 23 & Ha'ateiho & 1.4 & No & 0.98 & 279 & 609 & Fatai \\
\hline 24 & Tokomololo & 3.2 & No & 0.97 & 945 & 60 & Fatai \\
\hline 25 & Tokomololo & 2.6 & No & 0.88 & 854 & 73 & Fatai \\
\hline 26 & Pouvalu & 10.1 & No & 2.42 & 1032 & 161 & Fatai \\
\hline
\end{tabular}




\begin{tabular}{|c|c|c|c|c|c|c|c|}
\hline & Name & $\begin{array}{l}\text { Elevation } \\
\text { (m) }\end{array}$ & $\begin{array}{l}\text { Peaks and } \\
\text { ridges }\end{array}$ & $\begin{array}{c}\text { Slope } \\
(\%)\end{array}$ & $\begin{array}{c}\text { Distance to } \\
\text { coast (m) }\end{array}$ & $\begin{array}{l}\text { Distance to } \\
\text { fresh water }(\mathrm{m})\end{array}$ & Soil type \\
\hline 27 & Nuku'alofa & 15.2 & No & 1.44 & 190 & 545 & Sandy loam \\
\hline 28 & Takaunove & 1.3 & No & 0.28 & 83 & 1129 & Sandy loam \\
\hline 29 & Navai & 0.9 & No & 0.35 & 214 & 368 & Vaini \\
\hline 30 & Tapuhia & 1.7 & No & 2.83 & 927 & 243 & Vaini \\
\hline 31 & Tapuhia & 13.5 & No & 1.36 & 1100 & 87 & Vaini \\
\hline 32 & Kauvai & 0.8 & No & 1.71 & 69 & 44 & Vaini \\
\hline 33 & Kauvai & 26.6 & Yes & 2.8 & 420 & 289 & Lapaha \\
\hline 34 & Vainī & 10.3 & Possible & 2.87 & 167 & 307 & Vaini \\
\hline 35 & Vainī & 10.5 & Possible & 2.55 & 134 & 327 & Vaini \\
\hline 36 & Holonga & 8.6 & No & 1.06 & 179 & 169 & Vaini \\
\hline 37 & Holonga & 9.0 & No & 1.86 & 118 & 28 & Vaini \\
\hline 38 & Havelu Lahi & 34.2 & No & 0.47 & 2804 & 254 & Vaini \\
\hline 39 & Mala'e Vakapuna & 52.6 & Possible & 0.98 & 2759 & 117 & Vaini \\
\hline 40 & Fua'amotu & 60.9 & No & 0.06 & 898 & 429 & Lapaha \\
\hline 41 & Fua'amotu & 62.3 & No & 0.73 & 530 & 143 & Lapaha \\
\hline 42 & Nakolo & 35.3 & No & 12.72 & 380 & 4 & Sandy loam \\
\hline 43 & Ha‘asini & 34.8 & No & 0.64 & 535 & 184 & Lapaha \\
\hline 44 & Lavengatonga & 21.7 & No & 1.35 & 460 & 114 & Lapaha \\
\hline 45 & Tatakamotonga & 5.5 & No & 0.72 & 186 & 330 & Lapaha \\
\hline 46 & Olotele & 5.3 & No & 0.97 & 264 & 276 & Lapaha \\
\hline 47 & Lapaha & 6.7 & No & 0.75 & 555 & 130 & Lapaha \\
\hline 48 & Niutao & 0.3 & No & 0.6 & 210 & 286 & Lapaha \\
\hline 49 & Kolonga 'Uta & 1.7 & No & 3.18 & 1175 & 192 & Lapaha \\
\hline 50 & Kolonga 'Uta & 1.3 & No & 0.83 & 926 & 120 & Lapaha \\
\hline 51 & Kolonga & 2.6 & No & 0.52 & 348 & 203 & Lapaha \\
\hline
\end{tabular}

Source: Authors' data.

\section{Peaks and ridges}

Isolated peaks are scarce in the landscape and therefore fortifications on Tongatapu are rarely associated with high points. Only one fort, 33-Kauvai, is located on a defined peak or hill in order to utilise the natural defences of the area. 39-Mala'e Vakapuna in the south-east is located on a slight rise with an artificial central mound built on top of the rise. 27-Nuku'alofa, 34-Vaini and 35-Vaini are located on hillocks backing on to the lagoon. On the west side of the island the 14-Houma fort is located on a high point, with gentle slopes to the north and north-east, and a plateau extending to the south and west. Similarly, the forts of 19-'Utulau and 20-'Utulau are located on high points, with the terrain sloping to the north and a plateau to the south.

\section{Slope}

Slopes were calculated from the lidar DEM using the '3D analyst slope' function in ArcGIS and values were extracted for each point (Table 9.1). Sloping terrains might have been selected for defence in several cases as indicated by Firth (1927:68) in his description of Maori pa: 'Sloping ground, even if only of gentle gradient, confers a great advantage both in the construction of defensive works and the repelling of an assault'. The sites of 42-Nakolo (12 per cent slope) and 
10-Fahefa (8 per cent) are unambiguously associated with relatively steep slopes. The 42-Nakolo fort is located on a high elevation on the south-eastern side of the island, and 10-Fahefa is situated in the west on a slope facing the interior of the island. Both 22-Pea, in the centre of the island, and 49-Kolonga ' $U$ ta, on the north-east coast, are constructed on slopes in excess of 3 per cent. In the south-east, other forts on relatively steep slopes are 44-Lavengatonga and 43-Ha'asini. Six sites located on slopes in excess of 2-3 per cent are predominantly on the west side of the island; none is further east than 34-Vainī and 35-Vainī. All remaining sites are located on slopes less than 2 per cent.

\section{Distance from coast}

Distance from the coast was calculated by the 'Near 3D' algorithm in ArcGIS to the centre point of each fort (Table 9.1). Fortifications appear to be primarily located relatively close to the coast, particularly the accessible coast to the north of the island, with a median distance of $550 \mathrm{~m}$. Exceptions to this are the forts of 16-Matangiake (2894 m), 17-Hauloto (3233 m) and 18 -Hauloto $(3234 \mathrm{~m})$ in the centre of the island, and the sites of 38-Havelu Lahi $(2803 \mathrm{~m})$ and 39-Mala'e Vakapuna $(2758 \mathrm{~m})$ in the south-east. Fortifications close to the shore are found only on the north side of the island where access to land is readily available. Ten sites are located at a distance of less than $200 \mathrm{~m}$ from the coast, 7 sites at a distance of less than $300 \mathrm{~m}, 10$ sites are less than $600 \mathrm{~m}, 17$ sites less than $1300 \mathrm{~m}$ and only 6 sites are inland and more than $1300 \mathrm{~m}$ away from the coast. Thirteen sites are directly bordering the coastline or have sites open to the coast: 1-Kolovai $(220 \mathrm{~m}), 2-\mathrm{Ha}_{\text {avakatolu }}(119 \mathrm{~m}), 21$-Puke $(67 \mathrm{~m}), 27-N u k u$ '́lofa $(190 \mathrm{~m})$, 28-Takaunove (83 m), 22-Pea (276 m), 23-Ha'atehio (279 m), 32-Kauvai (69 m), 34-Vainī $(167 \mathrm{~m})$ and $35-$ Vainī $(134 \mathrm{~m}), 37-$ Holonga $(118 \mathrm{~m})$, 46-Olotele $(271 \mathrm{~m})$ and 48-Niutao $(210 \mathrm{~m})$.

According to historical records, Tongatapu was densely settled with population centres stretching from the northern coast about $1500 \mathrm{~m}$ into the interior (Beaglehole 1969; Martin 1820; Spennemann 2002). This was followed by an area of intensive arable land up to $4500 \mathrm{~m}$ from the north coast. The remaining land to the south coast was described as having only had limited cultivation and occasional settlement.

Comparing location selection to the two boundaries (Figure 9.2), only 18 (35 per cent) of the 51 identified fortifications fall outside the historically recorded intensively occupied zone close to the north coast. Seven fortifications (14 per cent), almost all on the west side of the island, are located in the zone of intensive agriculture, less than $4.5 \mathrm{~km}$ distance from the north coast. Almost all fortifications, with the exception of 14-Houma in the west and the south-east cluster at high elevations, fall in the first two zones and are either associated with the residential high population density zone or with the zone of intensive agricultural activity. The south-east cluster of sites is not associated with either of these zones, and forts there are located in areas that could have been pockets of intensive inhabitation or agriculture (note: there is a high mound density in the south-east area). 


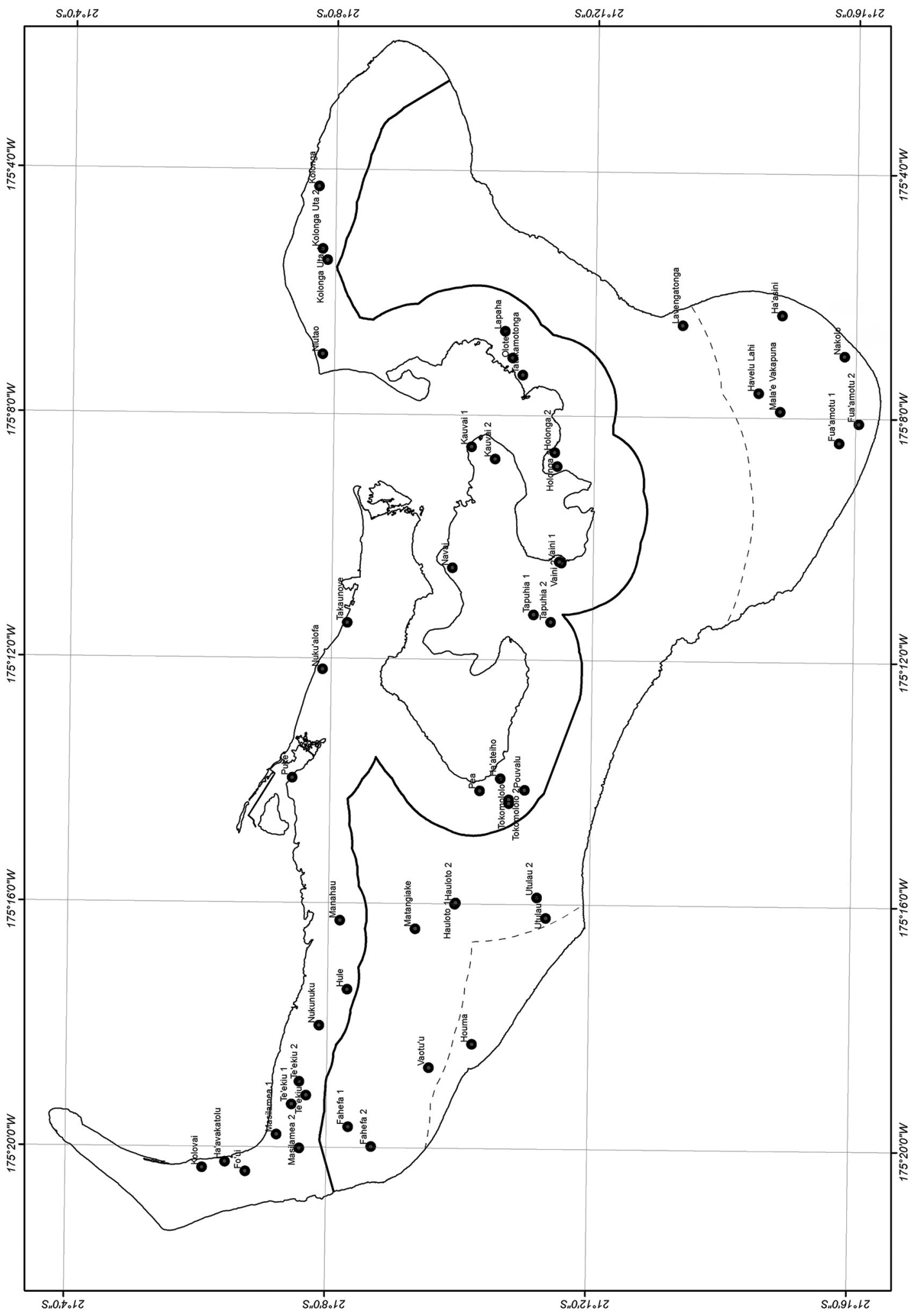

Figure 9.2. Map of Tongatapu with boundaries of $1500 \mathrm{~m}$ (solid black line) and $4500 \mathrm{~m}$ (dashed line) from the north shore showing area of intensive inhabitation and extent of intensive agriculture.

Source: Christian Reepmeyer, Geoffrey Clark, Phillip Parton, Malia Melekiola and David Burley. 


\section{Distance to water sources}

Access to freshwater is a persistent problem on Tongatapu as there are no surface water sources, such as lakes or rivers, on the island. The underlying karst limestone is highly permeable, which results in freshwater discharges in coastal environments. A rain-fed freshwater lens (GhybenHerzberg lens) with a thickness of about $20 \mathrm{~m}$ exists in the centre of the island (Spennemann 1989:11). However, this lens is substantially impacted by significant evapotranspiration. Surface run-off is extremely rare even during wet seasons. It has been suggested that only $25-30$ per cent of annual rainfall reaches the freshwater lens (Hunt 1979). Freshwater springs in the uplifted karst environment of the liku coast in the south are not recorded, but there are freshwater pools inside a number of cave systems (Iliffe and Sarbu 1990; Lowe and Gunn 1986).

Freshwater wells in coastal locations have been discussed by Spriggs (1997) and Hunt and Kirch (1988) as being abundant on Pacific Islands today. However, it is unclear whether this abundance of wells was also evident in earlier time periods. Early European explorers in the Pacific frequently discuss the difficulty of accessing potable water, particularly in the Pacific's eastern region. On Tongatapu, James Cook on his second voyage mentions the problem of accessing freshwater:

If nature has been wanting in any thing, it is in the article of fresh water, which as it is shut up in the bowels of the earth and for which they are obliged to dig wells, of these we saw only one, so that it is probable there are but few. (Beaglehole 1969:273)

There are only limited records of premodern wells on Tongatapu, although nine freshwater solution channels/springs have been identified exiting the northern palaeoshoreline (Spennemann 1989:201). There is a rich oral history about the importance of wells and access to freshwater on Tongatapu (McKern 1929); however, site location of these wells is not clear. Here we use the occurrence of depressions in the landscape as a potential indicator for the collection of rainwater. Depressions likely consist of collapsed karst features including sinkholes, caves and excavated wells, including areas where soil was quarried for earthwork structures. Based on lidar topography there is an abundance of depression features (Figure 9.3). The distance of depression features to the centroid of fortifications was calculated by the 'Near' function in ArcGIS.

It can be seen that most fortifications are located in relatively close vicinity $(<500 \mathrm{~m})$ to possible freshwater sources. However, six fortifications (6-Te'ekiu, 14-Houma, 16-Matangiake, 23-Ha'ateiho, 27-Nuku'alofa, and 28-Takaunove) were located at distances of $>500 \mathrm{~m}$, and 28-Takaunove most likely had no freshwater access at $1100 \mathrm{~m}$ distance (Table 9.1). Density maps of depression features using the 'Point density' function in ArcGIS (Figure 9.3) show that only a small number of fortifications are located in areas with a high density of depressions.

Increased freshwater access can explain the site location of defences at 12-Hule, 15-Manahau, 17-Hauloto and 18-Hauloto, 24-Tokomololo and 25-Tokomololo, 26-Pouvalu, 30-Tapuhia and 46-Olotele. On the other hand, sites such as 1-Kolovai, 2-Ha'avakatolu, 10-Fahefa, 19-'Utulau, 45-Tatakamotonga and 48-Niutao appear to be associated with areas that have some access to freshwater. Further, at least one fort, 42-Nakolo, has a cave with freshwater within the fortification, and at both 46-Olotele and 47-Lapaha forts the ditch excavations exposed areas where freshwater can be collected. 


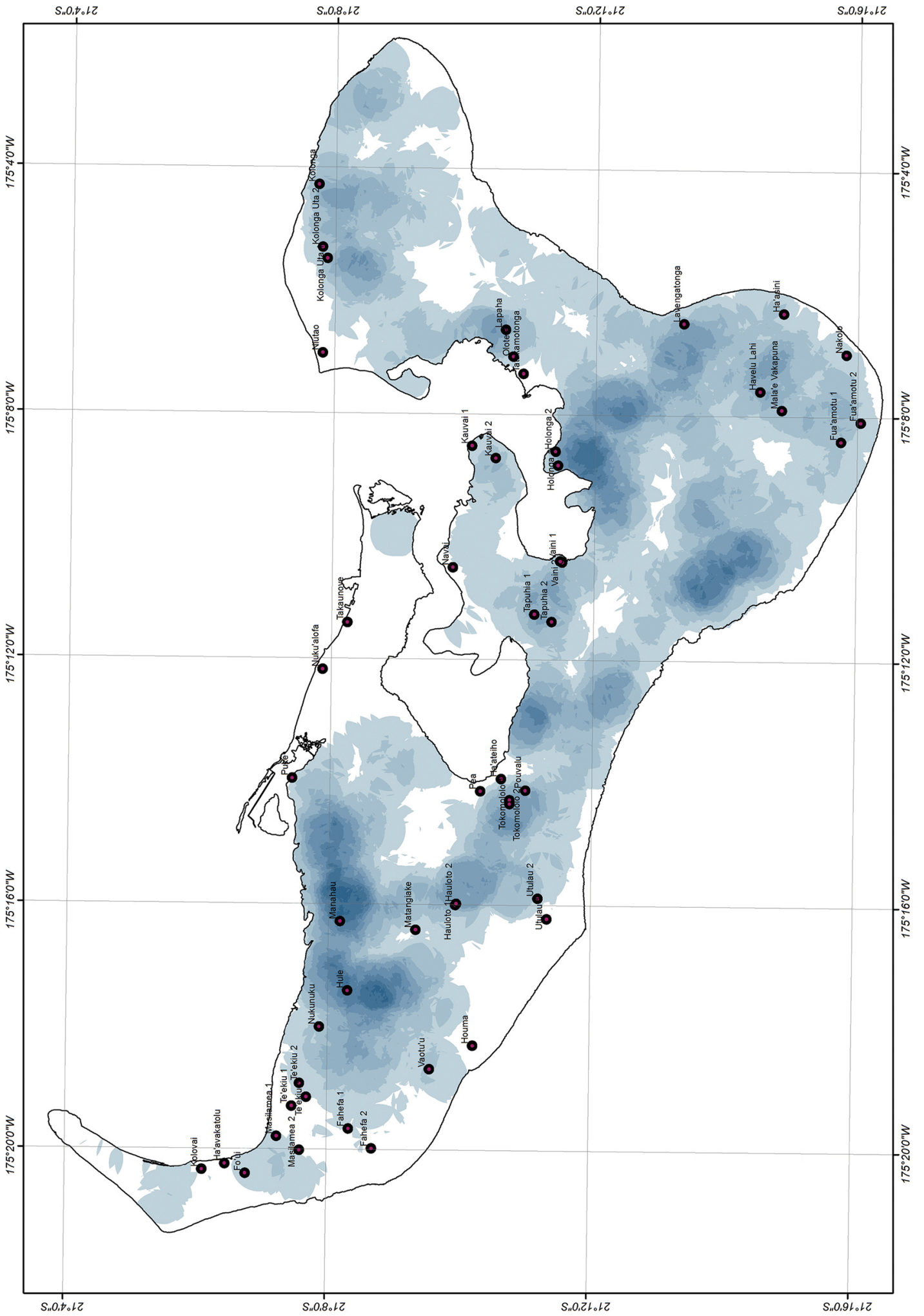

Figure 9.3. Density map of depressions indicating potential freshwater resources.

Darker shaded areas represent zones of higher depression density.

Source: Christian Reepmeyer, Geoffrey Clark, Phillip Parton, Malia Melekiola and David Burley. 


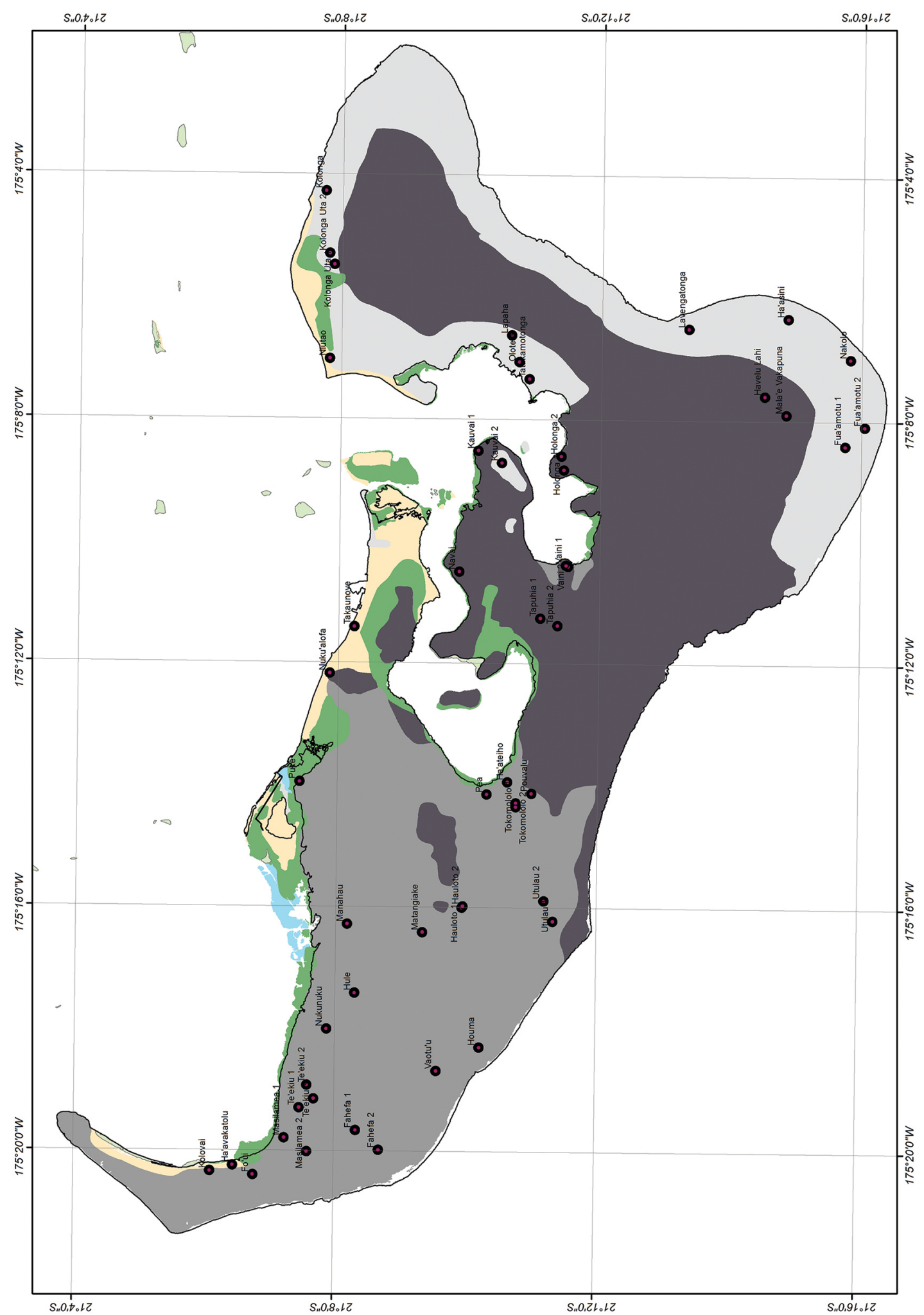

Figure 9.4. Map of Tongatapu with soil types based on the geospatial database from the Tongan Ministry Department for Land, Survey and Natural Resources.

Light-shaded areas around the coast in the east are Lapaha series soils, dark-shaded areas in the centre are Vaini series soils and grey areas in the west are Fatai series soils. Green area is mangrove and swamps; yellow is sandy loams and beach deposits.

Source: Christian Reepmeyer, Geoffrey Clark, Phillip Parton, Malia Melekiola and David Burley. 


\section{Soil}

Soils on Tongatapu are subdivided into three phases associated with tephra depositions on the island (Figure 9.4). The oldest phase are Lapaha series tephras mainly distributed on the east side of the island close to the coast. Vaini series clays are mainly situated in the centre-east area, and the Fatai series covers most of the west side of the island. All soils are acidic and highly fertile in the A-horizon, which ranges from around $30-40 \mathrm{~cm}$ thickness in the Lapaha series to $>100 \mathrm{~cm}$ in the Fatai series. Underlying older tephras are usually highly compacted and are not suitable for agriculture.

Forts can be found on all tephra soils. On the east side of the island, there seems to be a preference to construct fortifications on Lapaha soils overlying Vaini soils, with the exception of 38-Havelu Lahi and 39-Mala'e Vakapuna. Around the Fanga 'Uta Lagoon, all three soil series have been used to construct fortifications. The western side of the island is dominated by Fatai series soils and we do not see any preference for soil type in relation to fort location.

\section{Intervisibility}

Sightline analysis of fort location, using the 'Line of sight' algorithm in ArcGIS, which identifies visibility of two points if view is unimpeded, identified five clusters of forts in a $5 \mathrm{~km}$ radius (Figure 9.5). A north-east cluster includes 48-Niutao, 49-Kolonga' $U$ ta and 50-Kolonga' $U$ ta and 51-Kolonga; a south-east cluster of 38-Havelu Lahi, 39-Mala'e Vakapuna, 40-Fua'amotu and 41-Fua'amotu, 42-Nakolo, 43-Ha'asini and 44-Lavengatonga. These two clusters encompass all forts on the east side of the island. There is a central cluster of forts on the eastern shore of the Fanga 'Uta Lagoon that consists of 29-Navai, 30-Tapuhia, 32-Kauvai and 33-Kauvai, 34-Vaini and 35-Vainī, 36-Holonga and 37-Holonga, 47-Lapaha, 45-Tatakamotonga and 46-Olotele. Three sites on the north shore are located in the urban area of Nuku'alofa and form a fourth cluster with 21-Puke, 27-Nuku'alofa and 28-Takaunove. The last cluster comprises all sites in the west of the island, including those in the western part of the Fanga 'Uta Lagoon (Fanga Kakau sector) and sites on low-lying areas and uplifted limestone ridges.

For intervisibility analysis, the ArcGIS package 'Intervisibility' has been used, assuming that the visual height of a person is $1.8 \mathrm{~m}$ (Figure 9.6). The results replicate to a certain extent the sightline analysis as they show similar site clusters. However, several inconsistencies with the sightline model can be detected. Intervisibility of sites in the western lowlands shows that most possible sightlines are intervisible from each fort within a $5 \mathrm{~km}$ radius, including sites on high ground. We can separate the sites on the west side of the Fanga 'Uta Lagoon from this cluster as these are only visible from 19-'Utulau and 20-'Utulau on higher ground. There is no visibility between the Hauloto sites and the lagoon forts. The area between 15-Manahau, 16-Matangiake and the coastal sites of 21-Puke, 27-Nuku'alofa and 28-Takaunove represents a visual barrier; only 21-Puke is intervisible from the 15-Manahau fort.

Sites on the west and east side of the lagoon can also be separated into clusters. 26-Pouvalu is the only site visible from the east cluster and intervisibility is limited to the site of 31-Tapuhia. Sites in the east cluster are all intervisible, with the exception of 29-Navai, which is isolated and only visible from site 33-Kauvai, which is situated on a peak as described above. It appears that although there are sites located on the coast, such as 33-Vainī and 34-Vainī, these sites are not intervisible with the east end of the cluster that includes the 46-Olotele and 47-Lapaha forts.

In the north-east, the site of 48-Niutao is completely isolated; the three sites of 49-Kolonga 'Uta and 50-Kolonga 'Uta and 51-Kolonga are intervisible from each other, but are not visible from any other fort. Finally, the sites in the south-east are not visible from any of the other clusters. Interestingly, these sites are also not visible from each other, with the exception of 38-Havelu Lahi and 39-Mala'e Vakapuna, and 40-Fua'amotu and 41-Fua'amotu. 42-Nakola, 43-Ha'asini and 44-Lavengatonga are completely isolated from all sites. 


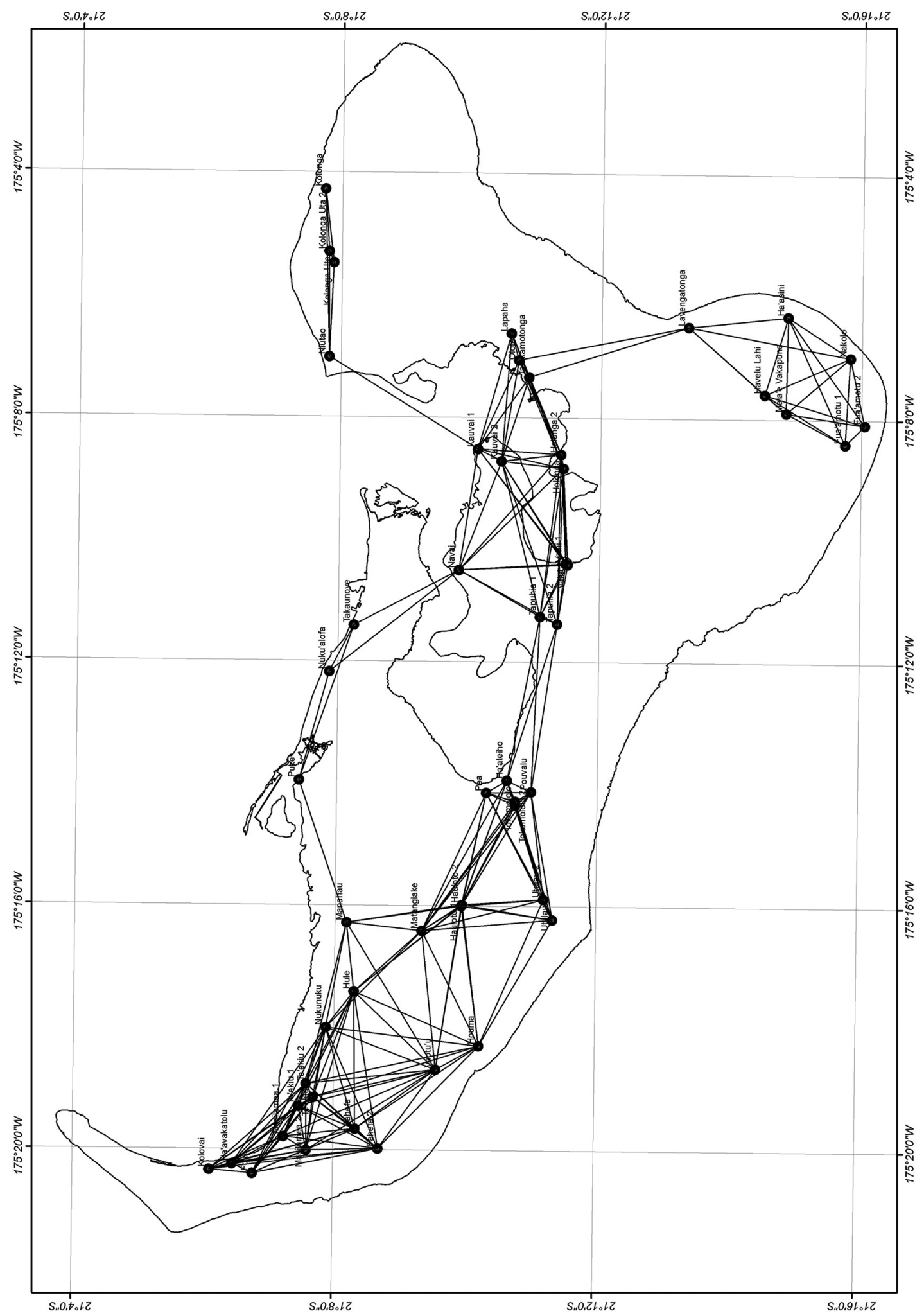

Figure 9.5. Sightline analysis of fort locations $5 \mathbf{~ k m}$ in distance from each other.

Source: Christian Reepmeyer, Geoffrey Clark, Phillip Parton, Malia Melekiola and David Burley. 


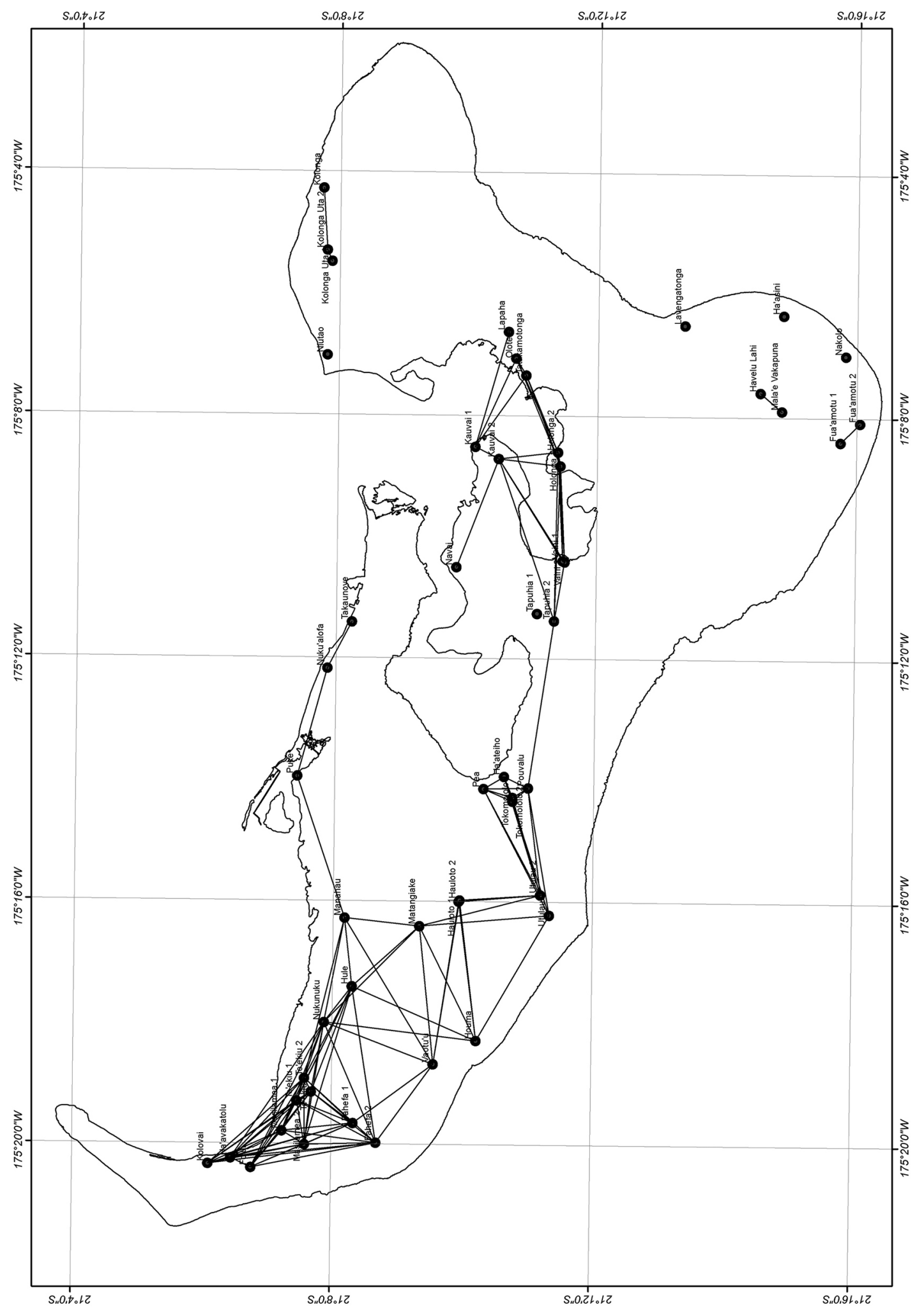

Figure 9.6. Intervisibility analysis of fort location.

Source: Christian Reepmeyer, Geoffrey Clark, Phillip Parton, Malia Melekiola and David Burley. 


\section{Discussion and conclusion}

There are few historical accounts that describe why forts were located in a particular place. In his account, William Mariner, who was in Tonga during the early nineteenth century, noted that:

thus was a violent civil contention induced, and the island was soon divided into several petty states. In the course of a little time, each party had built a fort for itself, so that there were at least twelve or thirteen different garrisoned places upon the island; each, in a state of warfare with all the rest, was determined to maintain its claims as long as it had strength to do so ... Besides their domestic troubles, every year they were disturbed by attacks from Finow, who made it his annual custom to make a descent upon one or other of their fortresses, and sometimes upon several of them in the same season; but they were all so well fortified and entrenched, that their enemy, however powerful, consisting of the Hapai people, under the command of Finow, and the Vavaoo people, under that of Toobó Nuha, had never succeeded, at the time of Mr. Mariner's first arrival, in taking or destroying a single fort; that is to say, during the space of seven or eight years. (Martin 1820:77)

This situation reflects the settlement pattern of the Tongan population soon after European contact when fortifications had proliferated as a consequence of chiefly competition and the breakdown of traditional society. It appears that at the time of Cook's visits to Tonga (1773-1777 CE) the densest population was located at the northern shore for about 1 to $1.5 \mathrm{~km}$ inland, with houses being built directly on the coast (Anderson in Beaglehole 1969; Ledyard 2005). Beyond this, plantations became bigger, but were more dispersed and the population became sparser. According to Anderson in 1777 CE (in Beaglehole 1969), closely packed plantations stretched inland for about up to $3 \mathrm{~km}$. The remaining area was described as uncultivated country covered with high grass. Occasional coconut trees could be seen, which Anderson took as evidence of cultivation. The steep liku coast in the south did not have any plantations and it was apparently uninhabited (Martin 1820; Spennemann 2002), although it is unclear whether any visits were made by European visitors to this area in the eighteenth century.

The low-lying relief of the island of Tongatapu means that hilltop fortifications, which are common in other parts of the Pacific, are almost absent from Tongatapu, with the exception of 27-Nuku'alofa, 33-Kauvai and 39-Mala'e Vakapuna. Overall, there is an unusual pattern where areas of raised elevation have not been used and fortifications were built nearby at lower elevations. For example, at the site of 18-Hauloto, a raised ridgeline is located approximately $2 \mathrm{~km}$ away, and at 1-Kolovai a ridgeline of around $12 \mathrm{~m}$ height is about $700 \mathrm{~m}$ away. This pattern is hard to explain, but might reflect a necessity to build forts close to community settlements and gardens rather than to take advantage of high areas.

The distribution of fortifications on Tongatapu indicates that all landforms were used, but forts are not distributed randomly through the landscape and can be grouped into five discrete clusters. Sightline analysis shows that these clusters are separated from each other by areas of limited visibility. Unfortunately, a detailed record of the placement of prehistoric population centres on Tongatapu is difficult to reconstruct, but there appears to be a correlation between modern villages and the presence of fortifications (Figure 9.7). The two main population centres of Nuku'alofa and Lapaha certainly have fortifications associated with them. It has been argued that beyond the defence of population centres, the protection of arable land is a priority for the placement of defensive structures (Field 2008; Sutton 1990), caused by the desire to maintain control over subsistence resources. In the west of Tongatapu, this premise appears to be fulfilled, as there are several forts located outside of dense population zones. In the east, however, fortifications do not occur at any distance from the coast, with the exception of two fortifications on high elevations in the south-east. The whole of Tongatapu is covered with fertile volcanic clays of different thickness that are suitable for intensive agriculture, and historical records show that all fertile arable land was farmed (Martin 1820). There is no marked difference between the soil fertility of Lapaha and Vaini 
soils in the centre and east, or from the Fatai soils of the west besides an overall increase of the fertile A-horizons (Cowie 1980). Apart from a correlation of A-horizon thickness, which increases from east to west, there is no indication that certain soil types increase the likelihood of fort construction.

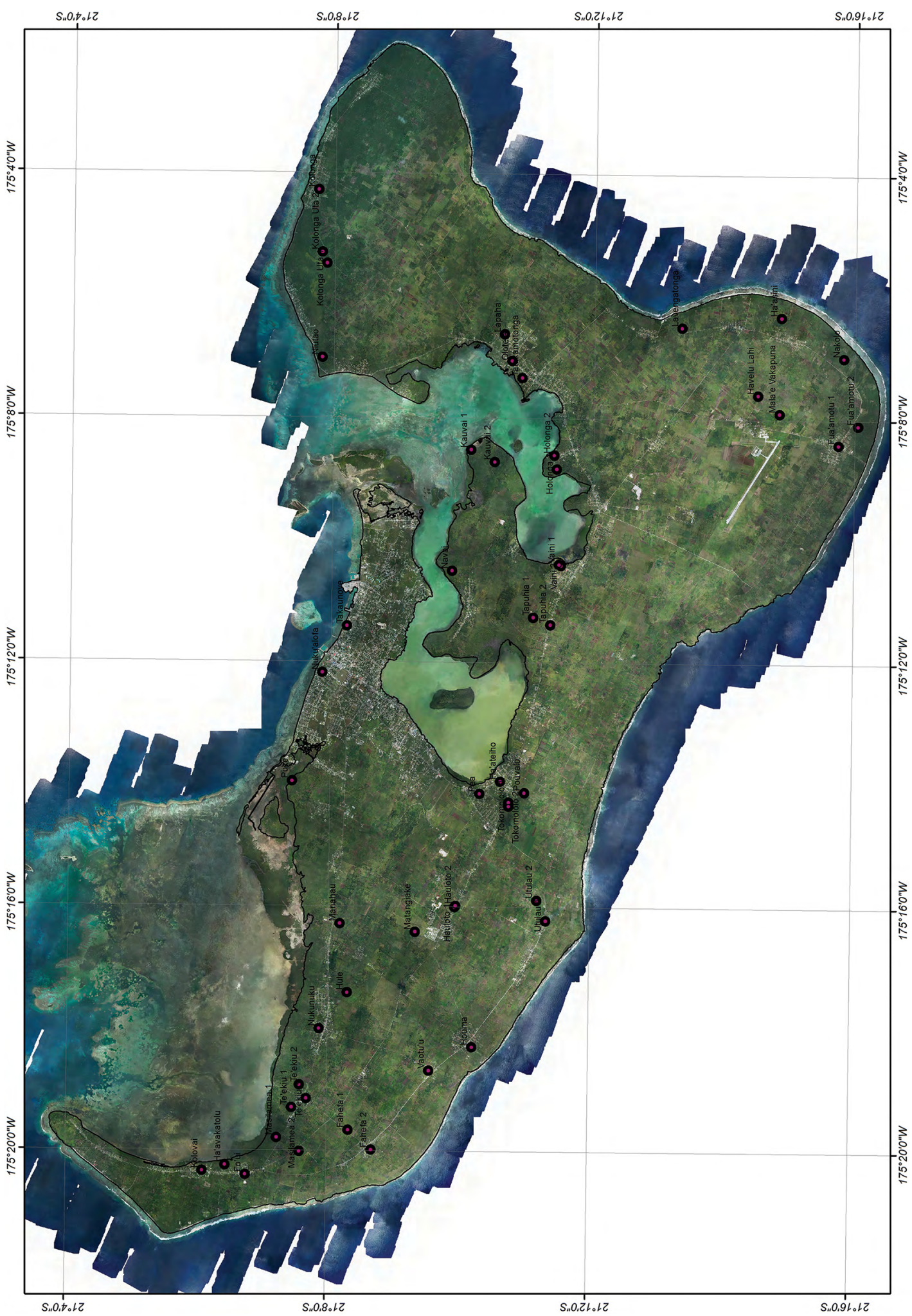

Figure 9.7. Ortho-image of Tongatapu showing modern settlements in relation to fort location.

Source: Christian Reepmeyer, Geoffrey Clark, Phillip Parton, Malia Melekiola and David Burley. 
The importance of environmental factors, such as precipitation decline during the 'Little Ice Age' (Field 2004), an increase in ENSO (El Niño-Southern Oscillation) variability (Kennett et al. 2006) and an associated decline in the carrying capacity of islands has been argued as the cause of fortification construction in the Late Holocene (Field and Lape 2010). There are no high-resolution climate records available for Tongatapu, and we used the placement of forts in relation to possible freshwater sources as a proxy for investigating on Tongatapu the significance of a scarce but essential resource. Under drought conditions the main source of freshwater would likely be depressions (natural and artificial) that tapped the water table; control of potable water is expected to lead to a higher density of defensive sites in the vicinity of wells, caves and springs (Field 2004; Lape and Chin-Yung 2008). Although it is unclear whether a climate-induced decline in subsistence yields was accompanied by the construction of fortifications on Tonga, the location of defensive earthworks does not correlate closely with potential freshwater sources. This might derive from the age of some fortifications, many of which are assumed to date to 1799-1852 CE (McKern 1929; Spennemann 1986; Wood 1975), a time when regional climate records show relatively low ENSO frequencies and high precipitation (Moy et al. 2002).

It appears that a key to understanding fortification placement in the Tongatapu landscape is the purpose of defensive sites. As noted above (Martin 1820; Parton et al. 2018), forts were not designed to withstand long-term sieges, but rather to give protection from short-term conflicts such as episodic skirmishes and raids. In this situation, an ideal defensive placement that maximally employed the available topographic and environmental variables appears to have been secondary to the construction of forts close to, or located in, cultivated and, especially, residential zones. The construction of early fortifications in the chiefly centre of Lapaha suggests that defence of the political core and supporting agricultural land was the primary purpose (Parton et al. this volume), and in Tongatapu some forts were likely fenced chiefly compounds that were extended in times of war by the addition of earthworks, while other forts were new constructions made at a strategic location in a chief's territory. Thus, reconstruction of the broader settlement pattern from the density of earth mounds (e.g. Freeland et al. 2016), the identification of land and sea transportation routes, and archaeological and historical data on settlements, forts and warfare is needed to refine our understanding as protection of arable land is unlikely to explain the position of all defensive earthworks on Tongatapu.

\section{References}

Anderson, A.J. 2016. The making of the Maori middle ages. Journal of New Zealand Studies NS23:2-18.

Beaglehole, J.C. (ed.) 1969. The voyage of the Resolution and Adventure 1772-1775. Cambridge University Press, Cambridge.

Best, S. 1984. Lakeba: The prehistory of a Fijian Island. Unpublished PhD thesis. University of Auckland, Auckland.

Best, S. 1993. At the halls of the mountain kings. Fijian and Samoan fortifications: Comparison and analysis. Journal of the Polynesian Society 102(4):385-447.

Clark, G., P. Parton, C. Reepmeyer, N. Melekiola and D. Burley 2018. Conflict and state development in ancient Tonga: The Lapaha earth fort. Journal of Island and Coastal Archaeology 13(3):405-419. doi.org/10.1080/15564894.2017.1337658.

Cowie, J. 1980. Soils from andesitic tephra and their variability, Tongatapu, Kingdom of Tonga. Soil Research 18:273-284. doi.org/10.1071/sr9800273.

ESRI 2011. ArcGIS Desktop: Release 10. Redlands. Environmental Systems Research Institute, California. 
Field, J.S. 1998. Natural and constructed defenses in Fijian fortifications. Asian Perspectives 37:32-58.

Field, J.S. 2004. Environmental and climatic considerations: A hypothesis for conflict and the emergence of social complexity in Fijian prehistory. Journal of Anthropological Archaeology 23:79-99. doi.org/ 10.1016/j.jaa.2003.12.004.

Field, J.S. 2008. Explaining fortifications in Indo-Pacific prehistory. Archaeology in Oceania 43:1-10. doi.org/10.1002/j.1834-4453.2008.tb00025.x.

Field, J.S. and P.V. Lape 2010. Paleoclimates and the emergence of fortifications in the tropical Pacific Islands. Journal of Anthropological Archaeology 29:113-124. doi.org/10.1016/j.jaa.2009.11.001.

Firth, R. 1927. Maori hill-forts. Antiquity 1:66-78. doi.org/10.1017/s0003598x00000077.

Freeland, T., B. Heung, D.V. Burley, G. Clark and A. Knudby 2016. Automated feature extraction for prospection and analysis of monumental earthworks from aerial LiDAR in the Kingdom of Tonga. Journal of Archaeological Science 69:64-74. doi.org/10.1016/j.jas.2016.04.011.

Gibbs, H.S. 1976. Soils of Tongatapu Island, Tonga. Department of Scientific and Industrial Research, Wellington.

Golson, J. 1969. Preliminary research: Archaeology in Western Samoa, 1957. In R.C. Green and J. Davidson (eds), Archaeology in Western Samoa, Volume 1, pp. 4-20. Bulletin of the Auckland Institute and Museum, Auckland.

Hunt, B. 1979. An analysis of the groundwater resources of Tongatapu Island, Kingdom of Tonga. Journal of Hydrology 40:185-196. doi.org/10.1016/0022-1694(79)90097-0.

Hunt, T.L. and P.V. Kirch 1988. An archaeological survey of the 'Manu'a islands, American Samoa. Journal of the Polynesian Society 97:153-183.

Iliffe, T.M. and S. Sarbu 1990. Anchialine caves and cave fauna of the South Pacific. National Speleological Society (NSS) News 48:88-96.

Kennett, D., A. Anderson, M. Prebble, E. Conte and J. Southon 2006. Prehistoric human impacts on Rapa, French Polynesia. Antiquity 80:340-354. doi.org/10.1017/s0003598x00093662.

Lape, P.V. and C. Chin-Yung 2008. Fortification as a human response to late Holocene climate change in East Timor. Archaeology in Oceania 43:11-21. doi.org/10.1002/j.1834-4453.2008.tb00026.x.

Ledyard, J. 2005. The last voyage of Captain Cook: The collected writings of John Ledyard. National Geographic Society, Washington.

Lowe, D. and J. Gunn 1986. Caves and limestones of the islands of Tongatapu and 'Eua, Kingdom of Tonga. Cave Science 13:105-130.

Martin, J. 1820. An account of the natives of the Tonga Islands in the South Pacific Ocean. Charles Ewer, Boston.

McKern, W.C. 1929. Archaeology of Tonga. Bernice P. Bishop Museum Bulletin 60. Bernice P. Bishop Museum, Honolulu.

Moy, C.M., G.O. Seltzer, D.T. Rodbell and D.M. Anderson 2002. Variability of El Niño/Southern Oscillation activity at millennial timescales during the Holocene epoch. Nature 420:162-165. doi.org/ 10.1038/nature01194.

Parry, J.T. 1987. The Sigatoka Valley pathway into prehistory. Bulletin of the Fiji Museum 9:1-134.

Parton, P.A., G. Clark, C. Reepmeyer and D. Burley 2018. The field of war: LiDAR identification of earthwork defences on Tongatapu Island, Kingdom of Tonga. Journal of Pacific Archaeology 9(1):11-24. 
Sand, C. 2008. Prehistoric maritime empires in the Pacific: Ga'asialili ('Elili) and the establishment of a Tongan colony on 'Uvea (Wallis, Western Polynesia). In A. Di Piazza, E. Pearthree and C. Sand (eds), At the heart of ancient societies: French contributions to Pacific archaeology, pp. 73-105. Cahiers de l'Archeologie en Nouvelle Caledonie, Noumea.

Smith, C. and E. Cochrane 2011. How is visibility important for defence? A GIS analysis of sites in the western Fijian Islands. Archaeology in Oceania 46:76-84. doi.org/10.1002/j.1834-4453.2011. tb00101.x.

Spennemann, D.H.R 1986. Zum gegenwärtigen Stand der archäologischen Forschung auf den TongaInseln-Ergebnisse und Perspektiven-TDARP Report 1. Anthropos 81:469-495.

Spennemann, D.H.R. 1989. 'ata 'a Tonga mo 'ata 'o Tonga: Early and later prehistory of the Tongan Islands. Volumes I and II. Unpublished PhD thesis. The Australian National University, Canberra.

Spennemann, D.H.R. 2002. Urbanisation in Tonga: Expansion and contraction of political centres in a tropical chiefdom. In P. Sinclair, W. Mutoro and G. Abung (eds), The development of urbanism from a global perspective: Proceedings of the Second World Archaeological Congress Intercongress, Mombasa, 1993. Swedish Central Board of National Antiquities, Stockholm.

Spriggs, M. 1997. The Island Melanesians. Blackwell, Oxford.

Sutton, D.G. 1990. The archaeology of the kainga: A study of precontact Maori undefended settlements at Pouerua, Northland, New Zealand. Oxford University Press.

Taylor, F.W. 1978. Quaternary tectonic and sea-level history, Tonga and Fiji, southwest Pacific. Unpublished PhD thesis. Cornell University, New York.

Wood, A.H. 1975. Overseas missions of the Australian Methodist Church. Volume 1: Tonga and Samoa. Aldersgate Press, Melbourne. 
This text is taken from Archaeological Perspectives on Conflict and Warfare in Australia and the Pacific, edited by Geoffrey Clark and Mirani Litster, published 2022 by ANU Press, The Australian National University, Canberra, Australia.

doi.org/10.22459/TA54.2021.09 